ISSN : $2302-1590$

E-ISSN: $2460-190 \mathrm{X}$

ECONOMICA

Journal of Economic and Economic Education Vol.4 No.2 (308-314)

\title{
ANALISIS PENGARUH MOTIVASI BELAJAR TERHADAP HASIL BELAJAR EKONOMI SISWA KELAS X SMA NEGERI 5 PADANG
}

\author{
Stevani \\ DosenProgram StudiPendidikanEkonomi STKIP-PGRISumbar \\ Jl. GunungPangilun No. 1 Padang Sumatera Barat \\ E-mail: Stevani060390@gmail.com \\ submited:2016.06.23 reviewed: 2016.07.01 accepted: 2016.07.01 \\ http://dx.doi.org/10.22202/economica.2016.v4.i2.669
}

\begin{abstract}
This study to determine the effect of learning motivation to wards the analysis of learning outcomes of economic class X SMA N 5 Padang; This type of research is descriptive and associative. The population in this study were all students of class X 2014/2015 school year. The research sample using proportional random sampling technique with a total sample of 110 students. The instrument used for research in the form of closed questionnaire. The assay used in this study were (1) descriptive analysis, (2) inductive analysis, (3) the classical assumption, (4) analsisi multiple regression, (5) the coefficient of determination, (6) test the hypothesis. Results of analysis of the data shows that it can be said that the students' motivation effect on student learning outcomes. This means that the rise of motivation to learn, the students will be semangkin climb the learning outcomes of economic class X SMA N 5 Padang. With the value of $R$ square of 0.739 , meaning that $73.90 \%$ of changes in the variables of learning outcomes can be explained by the variable motivation to learn while the remaining $26.10 \%$ influenced by other variables not included in this study.

Abstrak
Penelitian ini bertujuan untuk mengetahuianalisispengaruh motivasi belajar terhadap hasil belajar ekonomi siswa kelas X SMA N 5 Padang; Jenis penelitian ini adalah penelitian deskriptif dan asosiatif. Populasi pada penelitian ini adalah seluruh siswakelas X tahunajaran 2014/2015. Sampel penelitian menggunakan teknikpropotional random samplingdengan jumlah sampel sebanyak 110 siswa. Instrumen yang digunakan untuk penelitian berupa angket tertutup. Uji yang digunakan dalam penelitian ini adalah (1) analisis deskriftif, (2) analisis induktif, (3) uji asumsi klasik, (4) analsisi regresi berganda, (5) koefisien determinasi, (6) uji hipotesis.Hasil analisa data menunjukkan bahwa dapat dikatakan bahwa motivasi belajar siswa berpengaruh terhadap hasil belajar siswa. Artinya semakin naik motivasi belajar, siswa maka akan semangkin naik hasil belajar ekonomi siswa kelas X SMA N 5 Padang. Dengan nilai R square sebesar 0,739, artinya sebesar 73,90\% perubahan pada variabel hasil belajardapat dijelaskan oleh variabel motivasi belajarsedangkan sisanya sebesar 26,10\% dipengaruhi oleh variabel lain yang tidak termasuk kedalam penelitian ini.
\end{abstract}

Keywords :Learning Motivation And Learning Outcomes

C2016 Prodi Pendidikan Ekonomi STKIP PGRI, Padang 


\section{PENDAHULUAN}

Peningkatan sumber daya manusia merupakan langkah penting yang harus ditempuh dalam dunia pendidikan. Sumber daya manusia yang berkualitas dan berpotensi dalam arti yang luas yang diciptakan oleh dunia pendidikan akan membentuk sumber daya manusia yang berdaya saing tinggi dalam rangka menyikapi perubahan global yang akan mempengaruhi tata kehidupan bermasyarakat, berbangsa dan bernegara.

Berhasil atau tidaknya dunia pendidikan menciptakan sumber daya manusia yang berkualitas dan berpotensi salah satunya dipengaruhi oleh mutu pendidikan melalui pembinaan dan pengarahan anak didik menjadi manusia yang berakhlak mulia dan mampu berkembang dengan baik sesuai dengan kemampuannya serta bakat yang ada pada diri anak tersebut.

Peningkatan sumber daya manusia dapat dilakukan melalui proses pendidikan, baik pendidikan formal di sekolah maupun pendidikan non formal di luar sekolah. Pendidikan adalah usaha sadar dan terencana untuk mewujudkan suasana belajar dan proses belajar agar siswa secara aktif dapat mengembangkan potensi dirinya. Menurut Hasbullah (2013:1), "Pendidikan adalah usaha yang dijalankan oleh seseorang atau sekelompok orang agar menjadi dewasa atau mencapai tingkat hidup yang lebih tinggi".

Hasil belajar juga merupakan patokan utama untuk melihat keberhasilan pendidikan yang diselenggarakan di sekolah, termasuk salah satunya pada mata pelajaran ekonomi, untuk itu hasil belajar ekonomi yang di dapatkan siswa di sekolah harus mencapai KKM yang ditetapkan oleh sekolah tersebut. Kenyataan yang ada pada SMA N 5 Padang setelah dilakukan observasi pada Tanggsl 11 April 2015 pada siswa kelas X IPS, terlihat dari ratarata nilai lapor semester ganjil mata pelajaran IPS masih rendah. Hal ini dapat dilihat dalam tabel sebagai berikut:

Tabel 1. Data Nilai Lapor Semester Ganjil Mata PelajaraEkonomi Kelas X SMA Negeri 5 Padang

\begin{tabular}{|c|c|c|c|c|c|}
\hline \multirow[b]{2}{*}{ No } & \multirow[b]{2}{*}{ Kelas } & \multicolumn{4}{|c|}{ Tahun Ajaran 2014/2015 } \\
\hline & & $\begin{array}{l}\text { Jmlh } \\
\text { Siswa }\end{array}$ & $\begin{array}{l}\text { Tuntas } \\
\text { KKM }\end{array}$ & $\begin{array}{l}\text { Tidak } \\
\text { Tuntas } \\
\text { KKM }\end{array}$ & $\begin{array}{l}\text { Presntse } \\
\text { Ketntsan } \\
\text { Belajar }\end{array}$ \\
\hline 1 & X1 & 34 & 21 & 13 & $61,76 \%$ \\
\hline 2 & $\mathrm{X} 2$ & 32 & 17 & 15 & $53,13 \%$ \\
\hline 3 & X3 & 33 & 17 & 16 & $51,52 \%$ \\
\hline 4 & X4 & 33 & 20 & 13 & $60,61 \%$ \\
\hline 5 & X5 & 33 & 16 & 17 & $48,48 \%$ \\
\hline 6 & X6 & 32 & 16 & 16 & $50 \%$ \\
\hline 7 & $\mathrm{X} 7$ & 32 & 21 & 11 & $65,63 \%$ \\
\hline
\end{tabular}

Sumber: WakilKurikulum SMA N 5 Padang 
belajar Ekonomi di SMA N 5 Padang masih kurang memuaskan dan belum sesuai dengan apa yang diharapkan karena masih banyak yang berada dibawah Kriteria Ketuntasan Minimun (KKM) yang ditetapkan disekolah yaitu 80 .

Permasalahan ini timbul diduga karena pengaruh motivasi belajar sehingga hasil belajar siswa rendah.

\section{HASIL BELAJAR}

Masalah belajar adalah masalah bagi setiap manusia, dengan belajar manusia memperoleh keterampilan, kemampuan sehingga terbentuklah sikap dan bertambahlah ilmu pengetahuan. Jadi hasil belajar itu adalah suatu hasil nyata yang dicapai oleh siswa dalam usaha menguasai kecakapan jasmani dan rohani di sekolah yang diwujudkan dalam bentuk raport pada setiap semester.

$$
\text { Untuk }
$$

mengetahui perkembangan sampai di mana hasil yang telah dicapai oleh seseorang dalam belajar, maka harus dilakukan evaluasi. Untuk menentukan kemajuan yang dicapai maka harus ada kriteria (patokan) yang mengacu pada tujuan yang telah ditentukan sehingga dapat diketahui seberapa besar pengaruh strategi belajar mengajar terhadap keberhasilan belajar siswa. Hasil belajar siswa menurut W. Winkel (dalam buku Psikologi Pengajaran 1989:82) adalah keberhasilan yang dicapai oleh siswa, yakni prestasi belajar siswa di sekolah yang mewujudkan dalam bentuk angka.

Menurut Winarno Surakhmad (dalam buku, Interaksi Belajar Mengajar, (Bandung: Jemmars, 1980:25) hasil belajar siswa bagi kebanyakan orang berarti ulangan, ujian atau tes. Maksud ulangan tersebut ialah untuk memperoleh suatu indek dalam menentukan keberhasilan siswa.

Dari definisi di atas, maka
dapat diambil

bahwa hasil belajar adalah prestasi belajar yang dicapai siswa dalam proses kegiatan belajar mengajar dengan membawa suatu perubahan dan pembentukan tingkah laku seseorang. Untuk menyatakan bahwa suatu proses belajar dapat dikatakan berhasil, setiap guru memiliki pandangan masing-masing sejalan dengan filsafatnya. Namun untuk menyamakan persepsi sebaiknya kita berpedoman pada kurikulum yang berlaku saat ini yang telah disempurnakan, antara lain bahwa suatu proses belajar mengajar tentang suatu bahan pembelajaran dinyatakan berhasil apabila tujuan pembelajaran khususnya dapat dicapai.

Untuk mengetahui tercapai tidaknya tujuan pembelajaran khusus, guru perlu mengadakan tes formatif pada setiap menyajikan suatu bahasan kepada siswa. Penilaian formatif ini untuk mengetahui sejauh mana siswa telah menguasai tujuan pembelajaran khusus yang ingin dicapai. Fungsi penelitian ini adalah untuk memberikan umpan balik pada guru dalam rangka memperbaiki proses belajar mengajar dan melaksanakan program remedial bagi siswa yang belum berhasil. Karena itulah, suatu proses belajar mengajar dinyatakan berhasil apabila hasilnya memenuhi tujuan pembelajaran khusus dari bahan tersebut. 


\section{MOTIVASI BELAJAR}

Kata motivasi berasal dari bahasa Latin yaitu movere, yang berarti bergerak (move). Motivasi menjelaskan apa yang membuat orang melakukan sesuatu, membuat mereka tetap melakukannya,dan membantu mereka dalam menyelesaikan tugas-tugas. Hal ini berarti bahwa konsep motivasi digunakan untuk menjelaskan keinginan berperilaku, arah perilaku (pilihan), intensitas perilaku (usaha, berkelanjutan), dan penyelesaian atau prestasi yang sesungguhnya (Pintrich, 2003).

Menurut Santrock, motivasi adalah proses yang memberi semangat, arah, dan kegigihan perilaku. Artinya, perilaku yang memiliki motivasi adalah perilaku yang penuh energi, terarah, dan bertahan lama (Santrock, 2007). Dalam kegiatan belajar, maka motivasi dapat dikatakan sebagai keseluruhan daya penggerak di dalam diri siswa yang menimbulkan kegiatan belajar, yang menjamin kelangsungan dari kegiatan belajar dan memberikan arah pada kegiatan belajar, sehingga tujuan yang dikehendaki oleh subjek belajar itu dapat tercapai (Sardiman, 2000).

Sejalan dengan pernyataan Santrock di atas, Brophy (2004) menyatakan bahwa motivasi belajar lebih mengutamakan respon kognitif, yaitu kecenderungan siswa untuk mencapai aktivitas akademis yang bermakna dan bermanfaat mencoba untuk mendapatkan keuntungan dari aktivitas tersebut. Siswa yang memiliki motivasi belajar akan memperhatikan pelajaran yang disampaikan, membaca materi sehingga bisa memahaminya, dan menggunakan strategi-strategi belajar tertentu yang mendukung. Selain itu, siswa juga memiliki keterlibatan yang intens dalam aktivitas belajar tersebut, rasa ingin tahu yang tinggi, mencari bahan-bahan yang berkaitan untuk memahami suatu topik, dan menyelesaikan tugas yang diberikan.

Siswa yang memiliki motivasi belajar akan bergantung pada apakah aktivitas tersebut memiliki isi yang menarik atau proses yang menyenangkan. Intinya, motivasi belajar melibatkan tujuan-tujuan belajar dan strategi yang berkaitan dalam mencapai tujuan belajar tersebut (Brophy, 2004).

\section{METODE PENELITIAN}

Jenis Penelitian deskriptif adalah penelitian yang dimaksudkan untuk menyelidiki keadaan, kondisi, atau hal-hal lain terhadap suatu objek atau wilayah yang diteliti. Sedangkan penelitian Asosiatif adalah suatu penelitian yang mencari hubungan antara satu variabel dengan variabel lain, yaitu simetris kausal dan interaktif. Dengan desain penelitian deskriptif dan asosiatif, maka penelitian memungkinkan untuk menggambarkan hubungan antar variabel, menguji hipotesis, mengembangkan generalisasi, dan mengembangkan teori yang memiliki validitas yang universal (Arikunto, 2010: 3).

Penelitian ini di SMA Negeri 5 Padang yang beralamat dilakukan pada bulan November 2015.

Polulasi dalam penelitian ini adalah seluruh siswa Kelas $\mathrm{X}$ SMA N 5 Padang. yang terdaftar di tahun ajaran 2014/2015 sebanyak 229 orang. Teknik pengambilan sampel 
pada penelitian ini adalah propotional random sampling dalam penelitian ini jumbah sampel adalah 112 orang. Hasil Belajar dan motivasi belajar, diperoleh dari hasil penyebaran kuesioner yang telah diuji cobakan terlebih dahulu. Penyusunan angket atau kuesioner berpedoman kepada skala likert dengan beberapa alternatif jawaban dengan diberi bobot penilaian positif. Analisis yang digunakan dalam penelitian ini adalah analisis deskriptif dan analisis induktif yang terdiri dari uji ramsey, uji like lihood, uji normalitas, uji multikolonialitas, uji heteroskedastisitas, uji autokorelasi dan regresi linear berganda.

\section{HASIL PENELITIAN}

Hasil belajar yang dimaksud pada penelitian ini adalah dari nilai Lapor Semester Ganjil 2014/2015 mata pelajaran Ekonomi siswa kelas XSMA N 5 Padangyang terdaftar pada tahun ajaran 2014/2015.

Setelah melakukan penelitian terhadap 112 orang siswa mengenai hasil belajar Ekonomi, maka secara terperinci pendistribusian data variabel hasil belajar ekonomidapat dilihat pada Tabel 2 berikut:

Tabel 2. Distribusi Frekuensi hasil ujian akhir semester ilmu pengetahuan sosial (IPS) kelas VIII tahun ajaran 2014/2015 di SMP Negeri 12 Padang

\begin{tabular}{|c|c|c|c|}
\hline \multirow{2}{*}{ No } & \multirow{2}{*}{ Kelas Interval } & \multicolumn{2}{|c|}{ Frekuensi } \\
\cline { 3 - 4 } & $68-70$ & 17 & Fi \\
\hline 1 & $71-73$ & 7 & 7,17 \\
\hline 2 & $74-76$ & 16 & 16,16 \\
\hline 3 & $77-79$ & 20 & 20,20 \\
\hline 4 & $80-82$ & 18 & 18,18 \\
\hline 5 & $83-85$ & 14 & 14,14 \\
\hline 6 & $86-88$ & 6 & 6,06 \\
\hline 7 & $89-91$ & 1 & 1,01 \\
\hline 8 & & 112 & \\
\hline Jumlah & & 78 & \multirow{2}{*}{$100 \%$} \\
\hline Rata-rata & 90 & \\
\hline Maksimum & & 68 & \\
\hline Minimum & & \multicolumn{2}{|c|}{} \\
\hline
\end{tabular}

Sumber: Olahan Data Primer, 2015

Tabel 2 di atas menunjukkan bahwa 17 orang siswa memperoleh nilai hasil ujian akhirekonomi yang terendah yaitu berkisar antara 6870.hasil ujian akhir semester Ilmu Ekonomiyang tertinggi diperoleh oleh 1 orang, yaitu berkisar antara 89-91. 


\section{PEMBAHASAN}

\section{Pengaruh Motivasi Belajar Terhadap Hasil Belajar Ekonomi Siswa Kelas X SMA Negeri 5 Padang}

Berdasarkan hasil analisis data dan pengujian hipotesis yang telah dilakukan diperoleh hasil bahwa motivasi belajar berpengaruh signifikan terhadap hasil belajar Ekonomi siswa kelas X SMA Negeri 5 Padang. Hal ini dapat dilihat pada tabel yang menyatakan bahwa diperoleh nilai koefisien sebesar 0,451 , hal ini berarti bahwa semakin baik motivasi belajar maka akan semakin baik pula hasil belajar ekonomi yang diperoleh oleh siswa, begitu juga sebaliknya apabila motivasi belajar tidak baik maka hasil belajar IPS yang diperoleh oleh siswa SMA Negeri 5 Padang juga tidak akan baik. Berdasarkan distribusi frekuensi motivasi belajar maka diperoleh total rata-rata skor pada variabel motivasi belajar adalah 3,67 dengan rata-rata tingkat capaian responden (TCR) sebesar $73,40 \%$ berada pada kategori cukup. Berdasarkan hasil penelitian di atas diketahui bahwa motivasi belajar berpengaruh positif terhadap hasil belajar Ekonomi siswa kelas X SMA Negeri 5 Padang.

Hal ini sesuai menurut Hamalik (2011:158) mengatakan motivasi adalah perubahan energi dalam diri (pribadi) seseorang yang ditandai dengan timbulnya perasaan dan reaksi untuk pencapai tujuan.

Hasil penelitian ini sesuai dengan penelitian yang di lakukan oleh Lukman Sumadi (2012) dengan judul "pengaruh motivasi belajar dan pemanfaat fasilitas belajar terhadap motivasi belajar siswa terhadap mata pelajaran ekonomi siswa kelas XI IPS di SMA Muhammadiyah 2 Surabaya". Hasil penelitian menunjukan bahwa Motivasi belajar berpengaruh signifikan terhadap prestasi belajar.

\section{PENUTUP}

Berdasarkan hasil analisis data yang telah penulis dilakukan dapat disimpulkan sebagai berikut Motivasi belajar berpengaruh positif dan signifikan terhadap hasil belajar IPS siswa kelas VIII SMP Negeri 12 Padang. Hal ini dibuktikan dengan nilai koefisien sebesar sebesar 0,451 sedangkan untuk nilai $t_{\text {hitung }}(92,52)>$ $\mathrm{t}_{\text {tabel }}(1,98525)$ dengan nilai signifikan $<(0,000<0,05)$. Berarti ada pengaruh antara motivasi belajar terhadap IPS siswa kelas VIII SMP Negeri 12 Padang dengan artian apabila motivasi belajar ditingkatkan sebesar 0,451 satu satuan maka hasil belajar IPS siswa kelas VIII SMP Negeri 12 Padang akan meningkat pula sebesar 0,451 satuan.

Berdasarkan kesimpulan di atas maka penulis dapat memberikan saran atau masukan sebagai berikut: Dari hasil penelitian diperoleh motivasi belajar berada pada kategori cukup dengan TCR $73,40 \%$, dimana TCR terendah terdapat pada indikator tidak cepat bosan dengan tugas yaitu 69,90\%. Maka disarankan kepada Guru untuk dapat memberikan motivasi belajar kepada siswa tanpa membeda-bedakan, disaat siswa gagal dalam menjawab pertanyaan maka guru harus selalu memberi motivasi kepada anak agar lebih bersemangat, dan guru tidak beleh membanding-bandingkan 
antara siswa pintar dengan siswa yang bodoh.

\section{DAFTAR PUSTAKA}

10.22202/economica.2016.v4.2.669

Dalyono, M. (2007). Psikologi Pendidikan. jakarta: Rineka Cipta.

Arikunto, S. (2010). Prosedur Penelitian Suatu Pendekatan Praktik. jakarta: Rineka Cipta.

Hamalik, O. (2011). Proses Belajar Mengajar. jakarta: Bumi Aksara.

Astuti, T. (2010). Pengaruh Lingkungan Keluarga dan Cara Belajar Terhadap Hasil Belajar Siswa Kelas X Administrasi Perkantoran SMK Negeri 1 Payakumbuh, 1, 162-172.

Sumadi, L. (2012). Pengaruh Motivasi Belajar dan Pemanfaat Fasilitas Belajar Terhadap Mata Pelajaran Ekonomi Siswa Kelas XI IPS di SMA Muhammadiyah Surabaya.

Nurhasnah. (2013). Pengaruh Lingkungan Keluarga dan Efikasi Diri Terhadap Hasil Belajar Produktif IPS Siswa Kelas VII SMP Negeri 12 Padang.

Yusuf, R. (2011). Pengaruh Cara Belajar dan Lingkungan Sekolah Terhadap Hasil Belajar IPS Ekonomi Pada Siswa Kelas VIII SMP N 2 Bonjol, 1-15. 